Байкальский государственный университет, г. Иркутск, Российская Федерация

С. В. Костылева

Байкальский государственный университет, 2. Иркутск, Российская Федерация

\title{
ТЕХНОЛОГИЧЕСКАЯ ЭВОЛЮЦИЯ ПРОИЗВОДСТВ ПРОДУКЦИИ ИЗ ДРЕВЕСНЫХ ОТХОДОВ, ИХ ЭФФЕКТИВНОСТЬ
}

\begin{abstract}
АНнотАция. В стране в связи с увеличением объемов заготовки круглого леса, увеличиваются и масштабы лесных отходов, которые создают экологические и экономические проблемы. В данной статье представлена, разработанная авторами мировая и отечественная эволюция производства продукции из древесных отходов, которая позволила доказать, что, во-первых, длительность этапов освоения новых продуктов из древесных отходов во времени сокращается; во-вторых, Российская Федерация отстает от экономически развитых стран (США, Германия, Канада, Швеция) в производстве новых видов продукции из древесных отходов на 30-40 лет. Выявлены причины этого. С этой целью в статье дана оценка динамики мировых лесных ресурсов и ее особенности, исследованы тенденции мирового производства лесопродукции, так как они определяют длительность этапов технологической эволюции производства продукции из древесных отходов. Выявлены причины отставания Российской Федерации в освоении и производстве новой продукции и представлены методические рекомендации по преодолению отставания в сроках освоения новой продукции.

кЛючЕВЫЕ слОВА. Лесопродукция; древесные отходы; девственный лес; обезлесевание; лесные ресурсы; недревесная лесная продукция; эволюция производства. ИНФОРМАЦИЯ О СТАТЬЕ. Дата поступления 10 августа 2017 г.; дата принятия к печати 19 декабря 2017 г.; дата онлайн-размещения 29 декабря 2017 г.
\end{abstract}

G. V. Davydova Baikal State University, Irkutsk, Russian Federation

S. V. Kostyleva Baikal State University, Irkutsk, Russian Federation

\section{TECHNOLOGICAL EVOLUTION OF PRODUCTION OF WOOD WASTE PRODUCTS AND THEIR EFFECTIVENESS}

ABSTRACT. In connection with the increase in volume of harvesting roundwood in the country, the scales of forest waste that create environmental and economic problems also increase. This article presents the authors' view of the world and domestic evolution of production of wood waste products, which makes possible to prove that, firstly, the duration of the development stages of the new products from wood waste is reduced in time; secondly, the Russian Federation stands behind the economically developed countries (USA, Germany, Canada, Sweden) in production of new types of wood waste products for 30-40 years. The reasons for this are identified. For that purpose, the article assesses the dynamics of the world's forest resources and its features, and studies the trends in the world production of forest products, as they determine the duration of the technological evolution stages of the wood waste products production. The reasons for the lagging of the Russian Federation in development and production of the new products are revealed, and methodological recommendations for overcoming the lagging in terms of the development of the new products are presented.

\section{Baikal Research Journal}


KEYWORDS. Forest products; wood waste; virgin forest; deforestation; forest resources; non-timber forest products; production evolution.

ARTICLE INFO. Received August 10, 2017; accepted December 19, 2017; available online December 29, 2017.

Как мы уже отмечали [1], последнее десятилетие в стране и мире ведутся интенсивные поиски производства лесных отходов, в том числе и древесных.

В целом технологическую эволюцию производства продукции из древесных отходов можно представить так

\begin{tabular}{|c|c|c|c|c|c|}
\hline $\begin{array}{c}\text { Середина } \\
19 \text { века }\end{array}$ & $\begin{array}{c}\text { Конец } \\
19 \text { века }\end{array}$ & $\begin{array}{c}1940-\mathrm{e} \\
\text { годы }\end{array}$ & 1980-е годы & 2000-е годы & 2020 год \\
\hline $\begin{array}{l}\text { Произ- } \\
\text { водство } \\
\text { бумаги и } \\
\text { целлюлозы }\end{array}$ & $\begin{array}{l}\text { Производ- } \\
\text { ство виско- } \\
\text { зы (искус- } \\
\text { ственный } \\
\text { шелк) из } \\
\text { целлюлозы }\end{array}$ & $\begin{array}{l}\text { Произ- } \\
\text { водство } \\
\text { древес- } \\
\text { ных плит } \\
\text { (ДВП, } \\
\text { ДСП) }\end{array}$ & $\begin{array}{l}\text { Производство } \\
\text { ориентиро- } \\
\text { ванно-стру- } \\
\text { жечных плит } \\
\text { (OSP, OSB, } \\
\text { МДФ) }\end{array}$ & $\begin{array}{l}\text { Производство проч- } \\
\text { ных композиционных } \\
\text { древесно-полимерных } \\
\text { материалов, произ- } \\
\text { водство комбиниро- } \\
\text { ванных плит, пеллет, } \\
\text { топливных гранул }\end{array}$ & $\begin{array}{l}\text { Производство } \\
\text { наноцеллюлозы, } \\
\text { черных гранул } \\
\text { (пеллет), про- } \\
\text { дукции биоэнер- } \\
\text { гетики }\end{array}$ \\
\hline
\end{tabular}

Эта схема позволяет сформулировать следующие выводы по технологической эволюции:

- длительность этапов освоения новых продуктов из древесных отходов во времени сокращается (50-40-20-10 лет);

- на каждом этапе эволюционного цикла расширяется номенклатура возможного производства новой продукции из древесных отходов;

- шире используются для производства новой продукции отходы мягколиственной и низкокачественной древесины;

- расширяются химические и химико-механические способы обработки отходов для получения новой продукции;

- производство новых продуктов из древесных отходов способствует уменьшению загрязнения окружающей среды, а соответственно уменьшению размера экологических платежей за хранение отходов;

- расширяются во времени возможности использования древесных отходов для производства продукции, что позволяет сохранять от вырубки лесные массивы;

- она способствует повышению коэффициента использования древесины.

Серьезное отношение в мире к комплексному использованию лесных ресурсов (особенно вторичных) объясняется реализацией главной идеи мировой политики сохранения природных ресурсов, их рациональное и комплексное использование, сохранение биологического разнообразия и устойчивое управление лесами.

Наиболее серьезной проблемой управления лесами в мире сегодня считается проблема обезлесения - уничтожение лесов человеком и перевод их земель в другую категорию земель.

За период с 1990 по 2015 годы, по оценкам ФАО, произошло существенное изменение состояния лесов и лесопользования. В глобальном масштабе площадь лесов продолжает сокращаться. Так в 1990 г. общая площадь лесов мира составляла 4128 млн га; в 2010 г. - 4033 млн га, а к 2015 г. площадь лесов сократилась до 3999 млн га. Ежегодное сокращение составило 0,13 \%, что по меркам лесов в планетарном масштабе - серьезное ухудшение ${ }^{1}$.

До конца 19 в. быстрые темпы сокращения лесов наблюдались на Ближнем Востоке, в Западной и Центральной Европе, в Южной Азии, на Американском

${ }^{1}$ Глобальная оценка лесных ресурсов 2015 : настольный справочник // Продовольственная и сельскохозяйственная организация ООН (FAO). URL: http://www.fao.org/forest-resources-assessment/ru.

\section{Baikal Research Journal}

электронный научный журнал Байкальского государственного университета 
континенте, в Африке. В 20 в. географическое распределением утраченных лесных площадей изменилось: в умеренной и бореальной климатической зоне (например, Западная Европа, Северная Америка) убыль лесов замедлилась, площадь лесов постепенно стабилизировалась, но проблемы утраты лесного покрова актуализировались для тропической зоны и, особенно, развивающихся стран, расположенных в Южной Америке, Африки и др. Факторы, обуславливающие сокращение лесных угодий, однако, изменились: на первый план вышли макроэкономические рыночные механизмы и программы государственного развития стран, стимулирующие экспорт природных ресурсов, сопровождающиеся переселением народов, развитием крупного товарного экспортно-ориентированного сельскохозяйственного производства и создания дорожной инфраструктуры.

Самое большое ежегодное сокращение лесов в настоящее время наблюдается в странах с низким уровнем доходов. Самая крупная потеря лесов за период 19902015 гг. произошла в тропиках, а именно в Южной Америке, в Африке. Самые большие сокращения площади лесов в 2010-2015 гг. зафиксированы по таким странам как: Бразилия, Индонезия, Нигерия, Танзания. Убыль лесов в тропической климатической зоне с 2000 г. составляла 7 млн га в год. В Австралии в начале третьего тысячелетия основным фактором, вызывающим большие лесопотери, стали засуха и лесные пожары.

Статистические характеристики лесных ресурсов мира приведены в табл. 1.

Таблица 1

Характеристика лесов мира

\begin{tabular}{|c|c|c|}
\hline Показатели & $\begin{array}{l}\text { Значение } \\
\text { за } 2015 \text { г. }\end{array}$ & $\begin{array}{l}\text { Темп ежегодных изменений } \\
\text { (среднее за } 199002015 \text { гг.), \% }\end{array}$ \\
\hline Площадь лесов, млн га & 3999 & $-0,13$ \\
\hline $\begin{array}{l}\text { Площадь других участков земли, } \\
\text { покрытых лесной растительностью, млн га }\end{array}$ & 1204 & $-0,10$ \\
\hline Среднегодовое лесовозобновление, млн га & 27 & 1,57 \\
\hline Площадь естественного леса, млн га & 3695 & $-0,24$ \\
\hline в том числе девственный лес, млн га & 1277 & $-0,10$ \\
\hline Площадь лесопосадок, млн га & 291 & 1,84 \\
\hline Запасы лесных насаждений, млрд м ${ }^{3}$ & 531 & 0,03 \\
\hline Запасы лесных насаждений на 1 га м³ га & 129 & 0,16 \\
\hline
\end{tabular}

По показателю средней площади лесов на душу населения снижение составило от 0,8 га в 1990 г. до 0,6 га в 2015 г. (в данном показателе учтен и рост численности населения мира). Тенденция сокращения площади лесов на душу населения наблюдается уже на протяжении нескольких тысячелетий.

С 1990 по 2015 гг. чистая потеря площади лесов составила 129 млн. га, то есть примерно 0,13 \% в год. В настоящее время темпы убыли лесов все еще высоки, но заметна положительная тенденция к снижению. Чистые годовые потери лесных площадей в мире составили: с 1990 по 2000 гг. - минус 8,3 млн. га, с 2000 по 2010 гг. - минус 5,2 млн. га, с 2010 по 2015 гг. - минус 3,3 млн. га

В мировой структуре по состоянию на 2015 г. доля лесных земель в общей площади суши составляет $30,6 \%$. За 25-летний период произошло сокращение территорий суши, занимаемой лесами с 31,6 \% в 1990 г. до 30,6 \% в 2015 г. Причем в Азии наблюдается самая низкая доля суши, покрытая лесами (19 \%), по причине высокой плотности населения и развития сельского хозяйства. Самая высокая доля лесных земель - в странах Южной Америки (49\%). На втором

\section{Baikal Research Journal}

электронный научный журнал Байкальского государственного университета 
месте по континентам - Европа, включая Российскую Федерацию, где доля лесных площадей составляет $46 \%{ }^{2}$.

Руководство отдельных стран решает проблему обезлесения за счет масштабных лесопосадок, а также положительно влияет естественное расширение лесов на заброшенных участках сельскохозяйственного назначения, как это , например, происходит в России. Страны, лидирующие по годовым расширениям лесных территорий за период 2010-2015 гг. стали Китай, Австралия, Чили, США, Филиппины.

Структура лесных ресурсов мира представлена естественным лесом и лесопосадками. Естественные леса, к которым относятся девственные и другие самовосстанавливающие леса, занимали в 2015 г. 93 \% площади лесов мира (3,7 млрдга). C 2010 по 2015 гг. чистое сокращение площади естественных лесов соответствует 6,5 млн га в год, для сравнения в 1990-2000 гг. чистая убыль составляла 10,6 млн га в год. Очевидно замещение потери естественных лесов. Крупнейшие массивы естественных лесов находятся в Европе, причем 85 \% из них в Российской Федерации. Наибольшая потеря естественных лесов наблюдалась в последние годы в Южной Америки и Африке.

К категории девственных лесов в 2010 г. относилось 36 \% площади всех лесов, в основном эти леса Южной Америки, Центральной и Северной Америки. С 2000 г. площадь девственных лесов сокращается на 0,45 ежегодно, что оценивается как серьезное негативное изменение. Переоценка площадей девственных лесов в 2015 году показала, что 1277 млрд га являются девственными, что составляет менее 32 \% мировой площади лесов. Ежегодные темпы сокращения за 25 -летний период составил $0,10 \%$.

За последние 25 лет площадь лесопосадок увеличилась на 105 млн га и составляет $7 \%$ мировой территории лесов. 267 млн га в 2010 г. и 291 млн га в 2015 г. составляли территории лесопосадки. Благодаря лесопосадкам площадь лесов увеличивается ежегодно с 2010 по 2015 гг. на 3,3 млн га, однако эта цифра не покрывает потери естественного леса в размере 6,5 млн га ежегодно.

Лидируют по площади лесопосадок Китай, США, Российская Федерация, Япония, Индия - в совокупности 53 \% от этой площади. Пиковые темпы роста лесопосадок 5,9 млн га в год приходились на период с 2000 по 2005 гг. В 20002010 гг. площадь лесопосадок увеличилась примерно на 5 млн га в год. Затем в 2010-2015 гг. рост замедлился до 3,3 млн га в год. В последние годы уже проявилась новая тенденция в обеспечении поставок круглых промышленных лесоматериалов, за счет искусственно восстановленных лесов. В будущем прогнозируется усиление значимости лесопосадок в обеспечении древесной и недревесной лесной продукцией, что позволит снизить нагрузку на естественные леса [2].

В 2010 г. общий запас древостоя в мировом масштабе составлял 527 млрд м ${ }^{3}$ или в среднем $131 \mathrm{~m}^{3}$ на гектар площади лесов. Запасы древостоя по оценкам на 2015 г. равны 531 млрд $\mathrm{m}^{3}$, однако в расчете на 1 гектар произошло снижение на $0,16 \%$ в год в сравнении с 1990 г., и древостой достиг уровня $129 \mathrm{~m}^{3} /$ га. Приблизительный объем древостоя других участков земли покрытых лесной растительностью составил 15 млрд $\mathrm{m}^{3}$, или в среднем $13 \mathrm{~m}^{3}$ на 1 гектар. В период с 1990 по 2010 гг. зафиксировано незначительное изменение объемов древостоя: по абсолютному объему произошло снижение на $0,5 \%$ за 20 лет, а в расчете на 1 га наоборот, увеличение на $2,8 \%$.

Около 61 \% запаса лесных насаждений - это так называемая деловая древесина, то есть древесина коммерческих пород, достигшая коммерческого размера и растущая в районах доступных для лесозаготовки. В Северной Америке и Европе,

${ }^{2}$ Глобальная оценка лесных ресурсов 2015 : настольный справочник // Продовольственная и сельскохозяйственная организация ООН (FAO). URL: http://www.fao.org/forest-resources-assessment/ru.

\section{Baikal Research Journal}

электронный научный журнал Байкальского государственного университета 
включая Российскую Федерацию, доля древесины, пригодной для коммерческого использования, превышает 70 \% В составе древостоя хвойные породы по оценкам на 2010 г. составляли около 30 \% от общего запаса, а лиственные - $61 \%$.

По данным 2015 г. 1187 млн га (30 \%) мировых лесов предназначены для выполнения продуктивных функций, то есть используются для производства древесины и недревесной лесной продукции. Более половины этой площади сосредоточены в странах с высоким уровнем дохода и только $8 \%$ - в странах с низким уровнем дохода. $К 2015$ г. произошло небольшое сокращение продуктивных лесов на 13,4 млн га относительно уровня 1990 г. Еще 1049 млн га $(26 \%)$ лесов предназначены для многоцелевого использования, включающего обычно производство древесной и недревесной продукции. Две трети этой площади также приходится на страны с высоким уровнем дохода и около $10 \%$ - на страны с низким уровнем дохода. Площадь мировых лесов, предназначенных для выполнения продуктивных функций, с 1990 г. сократилась на 13,4 млн га, а площадь лесов многоцелевого использования, наоборот, увеличилась на 37,5 млн га. Причиной перевода в категорию многоцелевого назначения в основном являются изменения в лесном законодательстве разных стран, направленных на сбережение и охрану природы ${ }^{3}$.

Следовательно, одним из направлений для сокращения лесных ресурсов и их биологического разнообразия является снижение и прекращение темпов обезлесения. Этого можно достичь за счет постепенного расширения производства продукции из вторичного сырья и мягколиственной и низкокачественной древесины и сократить площади обезлесения минимум в 4 раза.

Давая оценку динамике мировых лесных ресурсов можно отметить:

- в глобальном масштабе площади лесов продолжают сокращаться, но география распределения утраченных лесных площадей изменилась. В Западной Европе и Северной Америке убыль лесов замедлилась, а в развивающихся странах, расположенных в Южной Америке, Африке и др. увеличилась;

- увеличиваются масштабы лесовосстановительных работ, которые способствуют снижению темпов обезлесевания лесных территорий. Но в мировом масштабе они не покрывают потери естественного леса в размере 6,5 млн га ежегодно. Лидируют по площади лесовосстановления Китай, США, Российская Федерация, Япония, отстают в последние годы Южная Америка и Африка;

- увеличиваются объемы искусственного лесовосстановления, в основном в Южной Америке и Африке, хотя в небольших объемах используются и в Северной Америке и Европе;

- уменьшился запас лесных насаждений в мировом масштабе на 1 га, на $0,16 \%$ в год. Это объясняется незначительным изменением состава древостоя, соответственно увеличением доли мягколиственной древесины.

Представляет интерес исследовать тенденции мирового производства лесопродукции, т.к. они определяют длительность этапов технологической эволюции производства продукции из древесных отходов. Связь эта проявляется в том, что чем выше глубина переработки древесных ресурсов, тем, во-первых, в меньшей степени происходит обезлесевание лесных территорий, во-вторых, уменьшаются объемы древесных отходов, в-третьих, вырубаются меньшие площади лесов для получения заданных объемов готовой лесопродукции.

За период с 1961 по 2015 гг. мировые объемы заготовки древесины увеличились на $148,5 \%$ и составили в 2015 г. 3713,681 млн м³. Страны с самыми высокими размерами вывозки древесины в 2015 г. приведены в табл. 2.

${ }^{3}$ Прогноз развития лесного сектора РФ до 2030 года. Рим : Продовольственная и сельскохозяйственная организация Объединенных наций, 2012. 86 с.

\section{Baikal Research Journal}

электронный научный журнал Байкальского государственного университета 
Таблица 2

Объемы вывозки древесины в 2015 г.

\begin{tabular}{|l|r|r|r|}
\hline \multicolumn{1}{|c|}{ Страны } & $\begin{array}{c}\text { Объем вывозки } \\
\text { древесины, тыс. }{ }^{3}\end{array}$ & $\begin{array}{c}\text { Доля от мирового } \\
\text { объема, \% }\end{array}$ & $\begin{array}{c}\text { Доля дровяной древесины } \\
\text { в объеме вывозки, \% }\end{array}$ \\
\hline США & 412917 & 11,2 & 10,74 \\
\hline Индия & 356151 & 9,59 & 86,10 \\
\hline Китай & 339683 & 9,15 & 50,78 \\
\hline Бразилия & 254400 & 6,85 & 46,43 \\
\hline Россия & 205507 & 5,53 & 7,30 \\
\hline Канада & 155997 & 4,20 & 97,97 \\
\hline Эфиопия & 111109 & 2,99 & 43,54 \\
\hline Индонезия & 110882 & 2,99 & 94,71 \\
\hline Конго & 87137 & 2,35 & 86,69 \\
\hline Нигерия & 75310 & 2,03 & 9,42 \\
\hline Швеция & 74300 & 2,00 & \\
\hline $\begin{array}{l}\text { Итого по 11 странам } \\
\text { с высоким объемом } \\
\text { вывозки }\end{array}$ & 2183393 & 58,79 & 50,25 \\
\hline Мир, всего & 3713681 & 100,00 & \\
\hline
\end{tabular}

На мировом уровне половина общего объема вывозимой древесины используется в качестве древесного топлива, однако доля дровяной древесины значительно варьирует в странах с разной категорией доходов, учитывающий фактически уровень экономического развития государства. ФАО использует разделение стран по доходу на четыре группы; высокий, выше среднего, ниже среднего и низкий уровень дохода. В странах с высоким уровнем доходов доля дровяной древесины составляет менее $17 \%$, в странах с уровнем доходов выше среднего около $40 \%$, а в странах с уровнем доходов ниже среднего и с низким уровнем доходов -86 и $94 \%$ соответственно ${ }^{4}$ В развитых лесопромышленных странах деловая древесина используется для производства пиловочника, фанерного кряжа, а также целлюлозно-бумажной промышленности, что свидетельствует о высоком уровне переработки. В менее развитых странах большой объем круглого леса идет на топливо [3].

В перспективе ФАО прогнозирует дальнейший рост спроса на лесные продукты и вероятное потребление древесного топлива в странах с высоким уровнем доходов, поскольку древесина является экологическим и возобновляемым источником энергии, однако большая часть древесного топлива будет производиться из древесины низкого качества и древесных отходов. В странах с низким уровнем доходов предполагается, что эта доля, скорее всего, останется неизменной или уменьшится ${ }^{5}$.

Глубину переработки древесины определяет динамика производства основных видов лесной продукции (см. табл. 3).

Наблюдается рост мирового производства всех видов лесной продукции, но структура производства меняется: увеличивается доля листовых древесных материалов, бумаги и картона. На 7 \% в 2015 г. по сравнению с предыдущим выросло производство древесных плит с ориентированной стружкой (OSB). Причиной является восстановление после кризиса 2008 г. жилищного рынка и переход к

${ }^{4}$ Прогноз развития лесного сектора РФ до 2030 года. Рим : Продовольственная и сельскохозяйственная организация Объединенных наций, 2012. 96 с.

${ }^{5}$ Глобальная лесная продукция 2015: факты и цифры // Продовольственная и сельскохозяйственная организация Объединенных наций. Рим : ФАО, 2011. URL: http://www.fao.org/3/a $6669 r . p d f$; Прогноз развития лесного сектора РФ до 2030 года.

\section{Baikal Research Journal}

электронный научный журнал Байкальского государственного университета 
более устойчивому экологическому строительству и строительным материалам [4]. Этот сектор растет в два раза быстрее, чем сектор традиционных листовых древесных материалов и пиломатериалов. Известно, что щепа является основным видом сырья для производства самых разных древесных материалов как поверхностной, так и глубокой переработки: древесных плит - волокнистых (ДВП, МДФ, НДФ) и стружечных (ДСП, OSB); целлюлозы; продуктов гидролизных производств (спирта, глюкозы, сорбита и др.); топливных брикетов; строительных и декоративных материалов. В щепу перерабатываются тонкомерные стволы деревьев, их вершинные части, обломки стволов, кусковые отходы, сучья, ветки, отходы шпона и др. [5]

Таблица 3

Производство лесной продукции в мире

\begin{tabular}{|c|c|c|c|c|c|c|c|}
\hline \multirow{2}{*}{ Вид продукции } & \multicolumn{4}{|c|}{$\begin{array}{c}\text { Объем производства } \\
\text { по годам }\end{array}$} & \multicolumn{3}{|c|}{$\begin{array}{c}\text { Относительный прирост, } \\
\%\end{array}$} \\
\hline & 1990 & 2010 & 2014 & 2015 & $\begin{array}{c}2015 / \\
1990\end{array}$ & $\begin{array}{c}2015 / \\
2010\end{array}$ & $\begin{array}{l}2015 / \\
2014 \\
\end{array}$ \\
\hline Круглый лес, млн м ${ }^{3}$ & 3536 & 3526 & 3680 & 3714 & 5,0 & 5,3 & 0,9 \\
\hline Пиломатериалы, млн м ${ }^{3}$ & 463 & 376 & 440 & 452 & $-2,3$ & 20,4 & 2,9 \\
\hline Листовые древесные материалы, млн м & 129 & 288 & 388 & 399 & 209,6 & 38,5 & 3,0 \\
\hline в т. ч. шпон, фанера, млн м ${ }^{3}$ & 53 & 104 & 161 & 171 & 220,5 & 63,9 & 6,1 \\
\hline $\begin{array}{l}\text { Стружечные и древесноволокнистые } \\
\text { плиты, млн м }{ }^{3}\end{array}$ & 76 & 34 & 227 & 228 & 201,9 & 4,1 & 0,7 \\
\hline Древесная целлюлоза, млн тн & 155 & 171 & 175 & 176 & 13,4 & 3,0 & 0,2 \\
\hline Рекупированная бумага, млн тн & 84 & 212 & 224 & 225 & 167,2 & 5,9 & 0, \\
\hline Бумага и картон, млн тн & 239 & 393 & 404 & 406 & 69,7 & 3,5 & 0, \\
\hline
\end{tabular}

За исследуемый период при росте отходов лесозаготовки и лесопереработки увеличивается и спрос на щепу (исходный материал для многих видов продукции). Это можно проследить по данным табл. 4.

Спрос на щепу растет как в мире, так и в Российской Федерации, да и условия для ее производства улучшаются. Щепа, производимая из древесных отходов и неликвидной древесины может применяться в качестве: топлива для выработке тепловой энергии, декоративной крашенной мульчи для садово-паркового хозяйства; щепы для копчения; наполнителя для производства арболита (деревобетона), сырья для изготовления топливных пеллет; подстилки для животных, птиц; культурного слоя для выращивания грибов и т. д. [5]

Таблица 4

Объем выпуска щепы в РФ по основным группам в 2010-2015 г2. тыс. плот. м $^{3 *}$

\begin{tabular}{|l|r|r|r|r|r|r|r|}
\hline \multicolumn{1}{|c|}{ Группы щепы } & \multicolumn{6}{|c|}{ Годы } & \multicolumn{1}{c|}{ Темп роста } \\
\cline { 2 - 8 } & \multicolumn{1}{c|}{2010} & \multicolumn{1}{c|}{2011} & \multicolumn{1}{c|}{2012} & \multicolumn{1}{c|}{2013} & \multicolumn{1}{c|}{2014} & \multicolumn{1}{c|}{2015} & 2010 гг. \\
\hline $\begin{array}{l}\text { Щепа для производства } \\
\text { целлюлозы }\end{array}$ & 3519,1 & 4598,7 & 4546,2 & 4301,2 & 4418,1 & 4769,7 & 124,1 \\
\hline $\begin{array}{l}\text { Щепа для производства } \\
\text { плит и прочих материалов }\end{array}$ & 1715,4 & 1881,1 & 2092,6 & 1929,6 & 2119,6 & 2227,2 & 129,2 \\
\hline Топливная щепа & 472,6 & 470,8 & 543,3 & 861,1 & 786,7 & 874,7 & 185 \\
\hline $\begin{array}{l}\text { Всего, Российская Феде- } \\
\text { рация }\end{array}$ & 5707 & 6957,5 & 7182 & 7091,9 & 7324,3 & 7871,6 & 138 \\
\hline
\end{tabular}

* Рассчитано авторами.

ЛПК России в 2015-2016 годах: итоги, перспективы, меры государственной поддержки // Научно-исследовательский и аналитический центр экономики леса и природопользования. URL: http:// www.umocpartner.ru/press-centr/news/conf

Российский статистический ежегодник. 2016 : стат. сб. М., 2016. 725 с.

\section{Baikal Research Journal}


Поставленные Европой цели по переходу на возобновляемые источники

энергии породили растущий спрос на биоэнергетику, что привело к резкому подъему производства древесных топливных гранул. При этом объем их производства вырос в десятикратном размере за последнее десятилетие [6].

В 2015 г. мировое производство древесных топливных гранул увеличилось до 28 млн т., то есть возросло на $8 \%$ по сравнению с уровнем предыдущего года в 26 млн т. и на $42 \%$ по сравнению с 20 млн т., произведенными в 2012 г. Прибалтийские государства (Латвия, Литва, Эстония) по производству топливных пеллет в 2015 г. обогнали Германию и Канаду и стали в совокупности вторым по величине их производителем и экспортером после США. Все это свидетельствует о том, глубина переработки за исследуемый период растет, но неравномерно: более высокими темпами в странах Северной Америки, Европы.

Для более полного понимания содержания этапов технологической эволюции производства продукции из древесных отходов в таблице 5 представлены крупнейшие страны по производству, потреблению, экспорту и импорту лесной продукции по данным 2015 г. $^{6}$

Таблица 5

Страны - производители, страны - потребители, страны - илпортеры, страны - әкспортеры лесной продукции в 2015 г., процент мирового рынка

\begin{tabular}{|c|c|c|c|c|}
\hline $\begin{array}{c}\text { Виды } \\
\text { продукции }\end{array}$ & $\begin{array}{c}\text { Страны - } \\
\text { производители }\end{array}$ & $\begin{array}{c}\text { Страны - } \\
\text { потребители }\end{array}$ & $\begin{array}{c}\text { Страны - } \\
\text { экспортеры }\end{array}$ & $\begin{array}{c}\text { Страны - } \\
\text { импортеры }\end{array}$ \\
\hline $\begin{array}{l}\text { Деловой } \\
\text { круглый } \\
\text { лес }\end{array}$ & $\begin{array}{l}\text { США (20\%) } \\
\text { РФ (10\%) } \\
\text { Китай }(9 \%) \\
\text { Канада }(8 \%) \\
\text { Бразилия (7\%) } \\
\text { Швеция }(4 \%)\end{array}$ & $\begin{array}{l}\text { США }(19 \%) \\
\text { Китай }(11 \%) \\
\text { РФ }(9 \%) \\
\text { Канада }(8 \%) \\
\text { Бразилия }(7 \%) \\
\text { Швеция }(4 \%)\end{array}$ & $\begin{array}{l}\text { РФ (16\%) } \\
\text { Новая Зеландия } \\
(12 \%) \\
\text { США }(9 \%) \\
\text { Канада }(5 \%) \\
\text { Австралия }(4 \%)\end{array}$ & $\begin{array}{l}\text { Китай (37\%) } \\
\text { Германия (7\%) } \\
\text { Австрия (6\%) } \\
\text { Швеция (6\%) } \\
\text { Финляндия (5\%) } \\
\text { Индия }(5 \%)\end{array}$ \\
\hline $\begin{array}{l}\text { Древесные } \\
\text { пеллеты }\end{array}$ & $\begin{array}{l}\text { США (26\%) } \\
\text { Германия }(7 \%) \\
\text { Канада }(7 \%) \\
\text { Швеция }(6 \%) \\
\text { Латвия }(6 \%) \\
\text { Франция }(4 \%) \\
\text { Эстония }(4 \%) \\
\text { Вьетнам }(4 \%) \\
\text { Португалия (4\%) } \\
\text { Австрия }(4 \%) \\
\end{array}$ & $\begin{array}{l}\text { Великобритания } \\
(25 \%) \\
\text { США (11\%) } \\
\text { Дания }(8 \%) \\
\text { Италия }(8 \%) \\
\text { Швеция }(6 \%) \\
\text { Германия }(6 \%) \\
\text { Респ. Корея (5\%) } \\
\text { Бельгия }(4 \%) \\
\text { Франция }(4 \%)\end{array}$ & $\begin{array}{l}\text { США (28\%) } \\
\text { Канада }(10 \%) \\
\text { Латвия }(10 \%) \\
\text { Вьетнам }(7 \%) \\
\text { РФ }(6 \%) \\
\text { Эстония }(5 \%) \\
\text { Португалия }(4 \%) \\
\text { Германия }(4 \%)\end{array}$ & $\begin{array}{l}\text { Великобритания } \\
(42 \%) \\
\text { Дания }(13 \%) \\
\text { Италия }(11 \%) \\
\text { Респ. Корея }(9 \%) \\
\text { Бельгия }(6 \%)\end{array}$ \\
\hline $\begin{array}{l}\text { Пиломате- } \\
\text { риалы }\end{array}$ & $\begin{array}{l}\text { США (17\%) } \\
\text { Китай }(16 \%) \\
\text { Канада }(10 \%) \\
\text { РФ (8\%) } \\
\text { Германия (5\%) } \\
\text { Швеция }(4 \%)\end{array}$ & $\begin{array}{l}\text { Китай }(23 \%) \\
\text { США 21\%) } \\
\text { Германия }(4 \%) \\
\text { Канада }(4 \%) \\
\text { Япония }(4 \%) \\
\text { Бразилия }(3 \%)\end{array}$ & $\begin{array}{l}\text { Канада }(23 \%) \\
\text { РФ (18\%) } \\
\text { Швеция }(10 \%) \\
\text { Финляндия }(6 \%) \\
\text { Германия }(5 \%) \\
\text { США (5\%) } \\
\text { Австрия }(4 \%) \\
\end{array}$ & $\begin{array}{l}\text { Китай }(21 \%) \\
\text { США (19\%) } \\
\text { Великобритания (5\%) } \\
\text { Япония (5\%) } \\
\text { Египет }(5 \%) \\
\text { Германия }(4 \%)\end{array}$ \\
\hline $\begin{array}{l}\text { Листовые } \\
\text { древесные } \\
\text { материалы }\end{array}$ & $\begin{array}{l}\text { Китай }(50 \%) \\
\text { США }(8 \%) \\
\text { РФ (3\%) } \\
\text { Канада }(3 \%) \\
\text { Германия }(3 \%) \\
\text { Бразилия }(3 \%)\end{array}$ & $\begin{array}{l}\text { Китай (48\%) } \\
\text { США (11\%) } \\
\text { Германия (3\%) } \\
\text { РФ (3\%) }\end{array}$ & $\begin{array}{l}\text { Китай (17\%) } \\
\text { Канада }(9 \%) \\
\text { Германия (7\%) } \\
\text { Малайзия (6\%) } \\
\text { РФ (5\%) } \\
\text { Таиланд }(5 \%) \\
\text { Франция (4\%) }\end{array}$ & $\begin{array}{l}\text { США (15\%) } \\
\text { Германия (7\%) } \\
\text { Япония (5\%) } \\
\text { Китай }(4 \%) \\
\text { Канада }(4 \%) \\
\text { Великобритания }(4 \%)\end{array}$ \\
\hline
\end{tabular}

${ }^{6}$ Об утверждении плана мероприятий по импортозамещению в ЛПК Российской Федерации : приказ Минпромторга от 31 марта 2015 г. № 657. URL: http://minpromtorg.gov.ru/common/upload/files.

\section{Baikal Research Journal}


Окончание табл. 5

\begin{tabular}{|c|c|c|c|c|}
\hline $\begin{array}{c}\text { Виды } \\
\text { продукции }\end{array}$ & $\begin{array}{c}\text { Страны - } \\
\text { производители }\end{array}$ & $\begin{array}{c}\text { Страны - } \\
\text { потребители }\end{array}$ & $\begin{array}{c}\text { Страны - } \\
\text { экспортеры }\end{array}$ & $\begin{array}{c}\text { Страны - } \\
\text { импортеры }\end{array}$ \\
\hline $\begin{array}{l}\text { Древесная } \\
\text { целлюлоза }\end{array}$ & $\begin{array}{l}\text { США (27\%) } \\
\text { Бразилия (10\%) } \\
\text { Канада (9\%) } \\
\text { Китай (9\%) } \\
\text { Швеция }(6 \%) \\
\text { Финляндия (6\%) } \\
\text { Япония (4\%) } \\
\text { РФ (3\%) }\end{array}$ & $\begin{array}{l}\text { США (26\%) } \\
\text { Китай (19\%) } \\
\text { Япония }(6 \%) \\
\text { Швеция }(5 \%) \\
\text { Канада }(4 \%) \\
\text { Финляндия (4\%) } \\
\text { Бразилия (3\%) } \\
\text { РФ (3\%) }\end{array}$ & $\begin{array}{l}\text { Бразилия (21\%) } \\
\text { Канада (17\%) } \\
\text { США (13\%) } \\
\text { Чили (8\%) } \\
\text { Индонезия (6\%) } \\
\text { Финляндия (5\%) } \\
\text { Швеция }(5 \%) \\
\text { Уругвай (4\%) }\end{array}$ & $\begin{array}{l}\text { Китай }(33 \%) \\
\text { США (20\%) } \\
\text { Германия }(8 \%) \\
\text { Италия }(6 \%) \\
\text { Респ. Корея }(4 \%) \\
\text { Франция }(4 \%) \\
\text { Япония }(3 \%)\end{array}$ \\
\hline $\begin{array}{l}\text { Бумага и } \\
\text { картон }\end{array}$ & $\begin{array}{l}\text { Китай }(27 \%) \\
\text { США (18\%) } \\
\text { Япония (6\%) } \\
\text { Германия (6\%) } \\
\text { Индия }(4 \%) \\
\text { Респ. Корея } \\
(4 \%) \\
\text { Канада (4\%) } \\
\text { Финляндия (4\%) }\end{array}$ & $\begin{array}{l}\text { Китай }(27 \%) \\
\text { США }(18 \%) \\
\text { Япония }(7 \%) \\
\text { Германия (5\%) } \\
\text { Индия }(4 \%) \\
\text { Италия }(3 \%)\end{array}$ & $\begin{array}{l}\text { Германия (12\%) } \\
\text { США (10\%) } \\
\text { Финляндия (9\%) } \\
\text { Швеция (9\%) } \\
\text { Канада }(7 \%) \\
\text { Китай }(7 \%) \\
\text { Австрия }(4 \%) \\
\text { Индонезия (4\%) }\end{array}$ & \begin{tabular}{|l} 
Германия (10\%) \\
США (9\%) \\
Великобритания (6\%) \\
Италия (5\%) \\
Франция $(5 \%)$ \\
Китай $(4 \%)$
\end{tabular} \\
\hline
\end{tabular}

По данным табл. 5 можно сформулировать следующие выводы:

- мировыми лидерами по выпуску лесной продукции с высокой добавленной стоимостью являются США, Китай, Германия, Канада, Швеция;

- к числу стран - универсалов, то есть производящих широкую линейку лесопродукции можно отнести США, Китай, Канаду, Швецию, РФ, стран, специализирующихся на производстве ограниченного числа видов лесной продукции Финляндию и Японию (древесная целлюлоза, бумага и картон);

- страны Юго-Восточной Азии, Южной Америки и Африки, заготовавливая большие объемы деловой древесины, используют от 50 до $97 \%$ ее объема, как дровяную древесину (Индия, Эфиопия, Индонезия, Конго, Нигерия), при этом импортируют продукцию лесопереработки (см. табл. 2);

- мировыми лидерами среди стран - экспортеров на отдельных рынках являются РФ (16 \% ) плюс на рынке, круглого леса; Канада (23\%) и РФ (18 \% ) - на рынке пиломатериалов; Китай $(17 \%)$ и Канада $(9 \%)$ - на рынке листовых древесных материалов; Бразилия (21\%), Канада (17\%) - на рынке древесной целлюлозы; США (28 \%), Канада (10\% ) - на рынке древесных пеллет; Германия (12\%), США $(10 \%)$, Финляндия и Швеция (по $9 \%$ ) - на рынке бумаги и картона.

В то же время схема технологической эволюции производства продукции из древесных отходов из РФ на основе выявленных тенденций мирового производства, потребления, экспорта и импорта позволяет заключить:

- РФ отстает от экологически развитых стран (США, Германия, Канада, Швеция) в производстве новых видов древесной продукции из древесных отходов на 30-40 лет;

- сырьевые возможности (объемы древесных отходов растут) позволяют РФ производить новые виды продукции, но технологическая отсталость замедляет этот процесс [7];

- в РФ практически ликвидирована отраслевая наука, лесное машиностроение сократилось даже за последнее десятилетие в 6 раз, объем импорта лесозаготовительной и деревообрабатывающей техники увеличился в 7 раз [9];

- лесная промышленность РФ является «догоняющей», так как сама не создает, а осваивает уже используемые на мировом рынке новые товары, технологии и технику для их производства $[9 ; 10]$;

\section{Baikal Research Journal}


- рыночные механизмы не заинтересовывают предприятия отрасли в переработке лесных отходов, а новые инструменты не выработаны.

Например, древесные плиты ДСП, ДВП на мировом рынке лесной продукции появились в 40-х годах 20-го столетия, а на отечественном - в 70-х годах того же столетия, такая же ситуация (отставание) с освоением ориентированно-стружечных плит OSB, MДФ, пеллет. Это отражается на экономических результатах работы отрасли, т.к. «сливки» снимают страны - первопроходцы по производству новой продукции. Наибольший эффект достигается за счет масштабов производства, но когда на мировой рынок с опозданием выходит наша страна с этой «новой» продукцией, то вынуждена снижать цены на нее для вхождения на этот рынок [11].

Маловероятно, что РФ быстро сократит деятельность этапов технологической эволюции производства продукции из древесных отходов.

В настоящее время практически утрачен широко накопленный передовой научно-технический и промышленный опыт комплексного использования древесины и ее отходов в результате ликвидации большинства прикладных научно-исследовательских и конструкторский отраслевых институтов потери кадрового потенциала специалистов.

Отечественный и зарубежный опыт показывает, что наилучшие экономические результаты достигаются там, где организовано рациональное использование лесных ресурсов при их глубокой переработке. Лучше всего эта цель достигается сочетанием поставок сырья для лесоперерабатывающих предприятий с организацией на местах лесопильных производств, деревянного домостроения, выпуска черновых заготовок различного назначения и т. п. Еще более высокой эффективности можно достичь, если наряду с этим развивать собственное энергообеспечение за счет утилизации древесных отходов и нереализуемых лесных ресурсов, что особо актуально в свете проблем изменения климата, появления киотских механизмов стимулирования энергоэффективности и роста целесообразности использования биотоплива [6].

Эффективность использования лесных ресурсов в регионах нашей страны во многом определяет развитие экономики государства и благополучие его граждан.

\section{Список использованной литературы}

1. Давыдова Г. В. Теоретические предпосылки развития организаци-онных форм межфирменной кооперации предприятий по переработке лес-ных отходов / Г. В. Давыдова, С. В. Костылева // Бизнес. Образование. Пра-во. Вестник Волгоградского института бизнеca. 2016. - № 4 (37). - С. 128-133.

2. Кривокоченко Л. В. Конъюнктура мирового рынка лесоматериалов и перспективы развития российского экспорта / Л. В. Кривокоченко // Рос-сийский внешнеэкономический вестник. - 2016. - № 2. - С. 71-81.

3. Иванова Д. А. Влияние финансового регулирования на импортоза-мещение в лесопромышленном комплексе России / Д. А. Иванова // Сибир-ская финансовая школа. 2015. - № 1 (114). - С. 73-77.

4. Прядилина Н. К. Анализ структурных изменений и тенденций разви-тия производства листовых древесных материалов на мировом рынке / Н. К. Прядилина // Решение проблем развития предприятий: роль научных иссле-дований. Материалы VIII Международной научнопрактической конферен-ции. (3 марта 2016 г.) - 2016 - С. 1-11.

5. Никольская В. Технологическая щепа - востребованный продукт / В. Никольская // ЛесПромИнформ - 2016. - № 8 (122). — С. 94-98.

6. Порфирьев Б. Н. «Зеленая» экономика: новые тенденции и направле-ния развития мирового хозяйства / Б. Н. Порфирьев // Научные труды: Ин-ститут народнохозяйственного прогнозирования РАН. - 2012. - Т. 10. - С. 9-33.

\section{Baikal Research Journal}


7 Проблемы развития лесного комплекса в регионе: сб. науч. тр. / ред. А. И. Бирюкова. - Иркутск : Изд-во БГУЭП, 2012. - 99 с.

8. Григорьев И. Состояние и перспективы развития лесного машино-строения в России / И. Григорьев, В. Кацадзе // ЛесПромИнформ. - 2015 - № 2 (108) - С. 80-82.

9. Глазьев С. Ю. О стратегии устойчивого развития экономики России / С. Ю. Глазьев, Г. Г. Фетисов // Экономические и социальные перемены: фак-ты, тенденции, прогноз. 2013. - № 1 (25). - С. 23-35.

10. Жћуравлев Ю. В. Основные направления обеспечения эффективного развития промышленных предприятий и условия их выбора / В. Ю. Журав-лев, Д. Ю. Матузов // Вестник Воронежского государственного университета инженерных технологий. — 2016 . № 1 (67). - С. 288-292.

11. Давыдова Г. В. Рынок леса : учеб.пособие / Г. В. Давыдова, Т. В. Горицкая. - Иркутск : Изд-во БГУЭП, 2004. - 300 с.

\section{References}

1. Davydova G. V., Kostyleva S. V. Theoretical prerequisites of developing organizational forms of intercompany cooperation of enterprises in forest waste processing. Biznes. Obrazovanie. Pravo. Vestnik Volgogradskogo instituta biznesa = Business. Education. Law. Bulletin of Volgograd Institute of Business, 2016, no. 4 (37), pp. 128-133. (In Russian).

2. Krivokochenko L. V. Conjuncture of timber product world market and prospects of developing Russian export. Rossiiskii vneshneekonomicheskii vestnik = Bulletin of Russian Foreign Economy, 2016, no. 2, pp. 71-81. (In Russian).

3. Ivanova D. A. The impact of financial regulation on import phase-out in Russian timber industry. Sibirskaya finansovaya shkola = Siberian Financial School, 2015, no. 1 (114), pp. 73-77. (In Russian).

4. Pryadilina N. K. Analysis of structural changes and trends in production development of leafy wood materials in the world market. Reshenie problem razvitiya predpriyatii: rol' nauchnykh issledovanii. Materialy VIII Mezhdunarodnoi nauchno-prakticheskoi konferentsii. ( 3 marta 2016 g.) [Solving problems of enterprise development: the role of scientific research. Materials of VIII International Scientific and Practical Conference. (March 3, 2016)]. 2016, pp. 1-11. (In Russian).

5. Nikolskaya V. Pulpchips are in-demand products. LesPromInform $=$ LesPromInform, 2016, no. 8 (122), pp. 94-98. (In Russian).

6. Porfiryev B. N. "Green" Economy: new trends and directions of world economy development. Nauchnye trudy: Institut narodnokhozyaistvennogo prognozirovaniya RAN = Scientific Works: Institute of National Economic Forecasting of the Russian Academy of Sciences, 2012, vol. 10, pp. 9-33. (In Russian).

7. Biryukova A. I. (ed.). Problemy razvitiya lesnogo kompleksa $v$ regione [Problems of regional forestry complex development]. Irkutsk, Baikal State University of Economics and Law Publ, 2012. 99 p.

8. Grigoryev I., Katsadze V. State and prospects of developing forest machinery in Russia. LesPromInform = LesPromInform, 2015, no. 2 (108), pp. 80-82. (In Russian).

9. Glazyev S. Yu., Fetisov G. G. On strategy of sustainable development of the Russian economy. Ekonomicheskie $i$ sotsial'nye peremeny: fakty, tendentsii, prognoz = Economic and Social Changes: Facts, Trends, Forecast, 2013, no. 1 (25), pp. 23-35. (In Russian).

10. Zhuravlev Yu.V., Matuzov D. Yu.Main directions for providing an effective development of industrial enterprises and conditions for their choice. Vestnik Voronezhskogo gosudarstvennogo universiteta inzhenernykh tekhnologii = Voronezh State University of Engineering Technologies. 2016, no. 1 (67), pp. 288-292. (In Russian).

11. Davydova G. V, Goritskaya T. V. Rynok lesa [Wood market]. Irkutsk, Baikal State University of Economics and Law Publ, 2004. 300 p.

\section{Информация об авторах}

Давыдова Галина Васильевна - доктор экономический наук, профессор кафедры экономики и управления бизнесом, Байкальский государственный университет, 664003, г. Иркутск, ул. Ленина, 11, e-mail: davidova@isea.ru.

\section{Baikal Research Journal}


Костылева Светлана Владилировна - аспирант, кафедра экономики и управления бизнесом, Байкальский государственный университет, 664003, г. Иркутск, ул. Ленина, 11, e-mail: svet2674@mail.ru.

\section{Authors}

Galina V. Davydova - Doctor habil. in Economics, Professor, Chair of Economics and Business Management, Baikal State University, 11 Lenin St., 664003, Irkutsk; e-mail: davidova@isea.ru.

Svetlana V. Kostyleva - PhD Student, Chair of Economics and Business Management, Baikal State University, 11 Lenin St., 664003, Irkutsk; e-mail: svet2674@mail.ru.

\section{Для цитирования}

Давыдова Г. В. Технологическая эволюция производств продукции из древесных отходов, их эффективность / Г. В. Давыдова, С. В. Костылева // Baikal Research Journal. 2017. - T. 8, № 4. - DOI : 10.17150/2411-6262.2017.8(4).22.

\section{For Citation}

Davydova G. V., Kostyleva S. V. Technological evolution of industries producing goods from wood waste and their effectiveness. Baikal Research Journal, 2017, vol. 8, no. 4. DOI: 10.17150/2411-6262.2017.8(4).22. (In Russian).

\section{Baikal Research Journal}

